90th Annual Meeting

of The American Phytopathological Society

November 9, 1998, Las Vegas, NV

\title{
Science in Transition: Lessons from the Past for Our Future
}

\author{
C. Lee Campbell
}

Department of Plant Pathology, North Carolina State University, Raleigh 27695.

We live in a time of change when some question the future of the science and art of plant pathology. It is a time when the real need to solve disease problems is unparalleled in our history. It is a time when new discoveries place us on the verge of epoch-making breakthroughs in our understanding of how pathogens interact with plants. It is a time in which we are developing practical solutions to disease problems in a world that more than ever before cannot afford to see yields of food and fiber crops limited by disease. It is also a time fraught with funding and organizational challenges in which the role of scientist, administrator, publicist, and fund-raiser have become merged into the persona of today's successful scientist and many question what it means to do science and to be a scientist.

The population of our world continues to increase. Within 50 years, we will see the population meter of Planet Earth pass the 10 billion mark. This means that with the coming food crisis there is an urgent need to increase the amount of food available to people. This is a challenge we cannot ignore.

The food production solution upon which we have relied throughout most of human history-move into new areas and plant more land-is no longer a possibility. The expansion of agriculture into new lands can provide some of the needed food for the future, but not most of it. And, in reality, not much of it. Increases in efficiency of food production, brought about in part by the management of diseases and insects, must be an element in answering world food needs.

Increases in food production are a challenge for all of the agricultural sciences. Catherine Woteki, acting Under Secretary for Research, Education, and Economics of the U.S. Department of Agriculture (USDA) noted recently that "Two fundamental changes face agriculture. The first is achieving long-term sustainability while maintaining profitability, minimizing negative environmental impacts, and developing strong rural and agricultural communities. The second is responsiveness to broad public concerns for safe, nutritious, and accessible foods" (5). I would add a third challenge for agricultural scientists: promoting the awareness among the general public of where food comes from.

Clearly then, our future will be one in which plant pathology as an art and a science must be in transition and must embrace the changes before us. But this is nothing new for our discipline. Plant pathologists have always been leaders in the transformation of the agricultural and life sciences. Momentous developments in our profession have been brought about in the last 100 years by insightful and dynamic individuals. Our predecessors became successful agricultural scientists by discovering and communicating practical and effective ways to solve plant disease problems. Our predecessors became successful biologists and life scientists by exploring and explaining many of the mysteries of the dynamic interactions

Publication no. P-1998-1130-02O between plants and their pathogens. Our predecessors, thus, have provided a legacy of successes in science and service, because they were able to adapt to and make positive use of the transitions of our science.

Plant pathology is a relevant and vital science today. We will continue to meet the challenges of the changing art and science of plant pathology. My objective in this address is to present several perspectives from the scientific legacy of plant pathology that may help to guide us today and tomorrow. I also wish to illustrate, through several historical examples, how plant pathologists have succeeded in the pursuit of relevant science and the application of their results by an informed clientele.

For plant pathology, the period from 1875 to 1908 was a period of unparalleled growth and innovation. It was a period of unprecedented growth of knowledge concerning plant disease. It was a period of unprecedented increase in the number of people and institutions that worked to solve the mysteries of plant disease and to provide practical and effective solutions to plant disease problems. This was the era when the first scientists who would refer to themselves as plant pathologists actually came upon the scene in the USDA, the state experiment stations, and the nation's land-grant universities. Plant diseases such as peach yellows, black rot of grape, late blight of potato, and stem rust of wheat were well known to farmers and city dwellers alike. Not only was it a time of general awareness of the consequences of plant diseases, but it was also a time when effective solutions to disease problems were being proposed and popularized. Scientists were achieving successes in the campaign against plant disease-successes that were recognized in the popular press and by the general populace.

It was a time when some of the first true solutions to disease problems became not only known but also practical. It was a time of transition when science was being applied to the solution of agricultural problems. It was an era when the federal government and the states provided increasing and significant support for agricultural sciences. It was the era of the miracle fungicide Bordeaux mixture, which provided disease control options that had never before been possible. It was also an era in which scientific selection for disease resistance became a reality.

Following this period of early practical service, the time between the founding of The American Phytopathological Society in 1908 and the first World War became one of expanding knowledge and growing professionalism for our nascent discipline. The foundation of APS was the culmination of a change in perspective, in how plant pathologists viewed themselves. Their growing base of knowledge about the interaction between plants and pathogens and the orientation toward science and practical service served to distinguish them from the botanists of the day. The growth of discipline-specific, graduate education in newly established departments of plant pathology at land-grant universities as well as the intensification of research at experiment stations and through the 
USDA also reflected the expanding knowledge and professionalism of the discipline.

One of the true visionaries of this period was Lewis Ralph Jones. For the first 20 years of his illustrious career, he was a member of the faculty at the University of Vermont, and from 1910 on, he was a distinguished leader on the faculty at the University of Wisconsin at Madison. He was an individual instrumental in the expansion of the science and service of plant pathology. He was a keen observer, a brilliant thinker, and a true visionary. In 1913, Jones commented, "I recognize clearly that the highest duty in plant pathology is service, and that the chief aim in that service is to lessen the losses from plant diseases" (1). To accomplish this, he related that "as fast as conditions permit, we must be moving on to the attack on the more fundamental problems, the performance of the more enduring service" (1). Jones recognized clearly not only that service was the key to the success of plant pathology but also that service in the long term would come from advances made through basic science.

The period from 1920 to about 1940 was a time of growth of the profession of plant pathology and a time of development of companies that had an interest in producing and marketing fungicides. It was a time when many key elements of fundamental knowledge about plants and their pathogens were discovered and the application of host resistance was of continuing importance. In the post-World War days of the 1920s, plant pathology was a science of growing national prominence. Diseases were still of real importance and, through efforts such as the barberry eradication program, widespread publicity about stem rust of wheat and its alternate host reached the entire population of the Midwest from farmers to city dwellers. The life cycle of stem rust of wheat even found its way into the standard curriculum of middle and high schools in the 13 upper midwestern states of the eradication area. Scientists continued as a source of information and solutions for a population of farmers in a country in which agriculture was still a major force, but a country in which growth of industry and urbanization were occurring at a rapid pace.

In the early 1940s, the world changed again for plant pathologists. The second World War brought about changes in many ways, but it also brought about unparalleled opportunities for the practice and science of plant pathology. These opportunities came about through breakthroughs in organic chemistry and the general application of technology to scientific problems. It was an era of big science with magnanimous support at the federal level. It was an era of growing importance of the chemical industry and an era of growing successes with pesticides and, indeed, better living through chemistry.

In the aftermath of the second World War, there was a time of rapid growth in American industry and in U.S. universities. With the ever increasing adoption of organic fungicides by farmers, employment opportunities for plant pathologists in industry became a reality. Also, it was a time of growth and expansion in university departments. Public and private monies were available for the pursuit of science-basic science, science aimed at the understanding of the very processes of life. Practical solutions to plant disease problems appeared to be just around the corner and would be provided by the miracle fungicides. As a result, many plant pathologists changed their orientation from practical research aimed at solving problems in the short term to an orientation of fundamental, scientific inquiry.

Thus, it was during the era from 1940 to 1960 that plant pathologists made their second major transition from a profession in which a majority of individuals were disease fighters and practical problem solvers to one in which practical problems were still being solved, but the main emphasis was on the quest to understand plant disease and to understand the physiology of how pathogens interacted with plants. Plant pathology became, at that time, more a life science and less an agricultural science. Plant pathologists still coveted the mantle of practical respectability with regard to solving farmers problems, but the path from the laboratory to the field became less well worn and perhaps even became longer and less traveled. The practical problems of farmers would be solved through the use of organic fungicides and resistant varieties. The impact of plant diseases did, thankfully, decrease, and the awareness of these diseases on the part of the general populace began to decline.

The world changed for plant pathologists again in the early 1960s. Rachel Carson published her book Silent Spring in 1963, and the halcyon era of organic pesticides came to a pretty abrupt end. Fungicides, although ecologically less offensive than many of the insecticides of the era, were implicated as being a problem, because they were, after all, pesticides. Somewhere in the debate of the early 1960s, the tremendous benefits, the revolutions in agriculture and human health brought about by organic pesticides, were lost or at least minimized. And, for a large segment of the population, agricultural practices became suspect and were viewed as damaging to the environment. While this view is certainly not without some merit, the 1960s and 1970s were also the time when the American public became overwhelmingly separated from its agricultural roots. The American people were discovering what would become one of the perceived truths of the 1980s and 1990s-food comes from the supermarket.

Another factor that came upon us in the 1960s was that we, as plant pathologists, had done the practical side of our jobs well. Losses of food and fiber due to plant diseases were nowhere near the magnitude of those experienced even in the 1920s or the 1940s. Pesticides, resistant varieties, better cultural practices, better methods of processing and storing foods, and worldwide rapid transport of food items had all brought about a safe, reliable, and relatively inexpensive food supply - the likes of which the population of the United States had never seen. Life was good, but food-what did that have to do with agriculture?

At the same time, we plant pathologists had discovered new worlds of endeavor from studying epidemics to probing the molecular biology of pathogens and the plants on which they live. We continued throughout the 1970 s, 1980s, and 1990s to strengthen the life science component of our discipline. We became convinced, as L. R. Jones had suggested in 1913, that the long-term answers to plant disease problems came through understanding how pathogens interact with plants. And at colleges and universities, the era of the competitive grant not only was born but became the standard method of operation for research programs. Agrichemical companies became multinational giants and assumed their rightful role as major players in research on plant diseases and the solutions to the problems of plant diseases for growers. Profit, of course, remained an important factor for the agrichemical industry, but the road to profit was known to be paved with the results of solid, reliable science done in the laboratories and in the field. As plant pathologists, we became, through necessity, less connected to our agricultural roots, our practical side, in part because that is the way of society as a whole in the 1990s but also because we and our predecessors had done such a good job in solving plant disease problems.

Plant diseases, however, are still important. To producers, these diseases can be of paramount importance on a local or even regional basis. One need only look to the recent and continuing epidemics of late blight of potato in the northeastern United States and of Fusarium scab of wheat in the upper Midwest to realize that major epidemics are still with us. But, by in large, the general public is not really aware of plant diseases. Also, because of how we gain funding to do science at land-grant universities today, a majority of us are not working directly on solving practical and immediate plant disease problems.

And what of those scientists in industry, who in the 1950s, 1960s, and 1970 s were viewed by some as second-class citizens in the scientific establishment of plant pathology? The company scientists of the 1980s and 1990s are quickly becoming the acknowledged 
leaders in many areas of plant pathology research. There is no question today that scientists working for major, multinational corporations are making some of the greatest advances in understanding and solving plant disease problems. The importance of their contribution is unquestioned, and the magnitude and scope of their accomplishments are increasing. They have the outstanding individuals, the resources, and the opportunities needed to be leaders in the profession, and they are.

What lessons can we draw from our past as plant pathologists that will help us as we encounter the future?

First, our predecessors succeeded because it was clear that their work, the discoveries they made, and the practices they recommended were relevant. Is plant pathology relevant today? Will it be relevant tomorrow? Yes, indeed. Regardless of current urban perceptions, plant diseases still do cause major problems in the production of food and fiber crops. We have not tipped the ecological balance so far in our favor that plant pathogens are in any danger of extinction. We must each make a greater effort in reaching out to inform the public about plant diseases and about what it is that we do. We have to tell our story-beginning with the fact that food comes from plants and plants are part of agriculture. It is the responsibility of every plant pathologist to do so. As the President's Science Adviser, Neal Lane noted in an article in the September 15, 1998, issue of USA Today, "The public feels they really don't understand science very well and would like to know more. So it behooves us to do everything we can to ensure that the largest number of people can get excited in the same way that we are about science and can understand how it applies to their lives" (2). The noted astronomer Carl Sagan perhaps put it even more clearly in 1995 when he wrote in his book The Demon Haunted World that "It would be an odd flirtation with suicide for scientists to oppose competent popularization. What the public understands and appreciates, it is more likely to support" (4).

Second, we must always be vigilant in asking how we are doing in balancing the agricultural and life science components of our discipline. We must strive to balance our quest for new knowledge with the necessity of new solutions to real world problems. This is particularly true for those of us at land-grant universities and in government service. G. R. Lyman of the USDA put this quite well when he addressed a joint session of the Botanical Society of America and The American Phytopathological Society in Baltimore on December 26, 1918. He said, "The value of any discovered truth is in the end determined by its usefulness, by its connection with other facts already known or yet to be discovered, and by its ultimate power for the uplifting of the world, physically, intellectually and morally. Scientific research for its own sake gives but a selfish joy, and may lead in the end to dry rot and to the scrap pile of human progress" (3).

Finally, we must embrace the new opportunities and partnerships that are available to us through the cooperation between scientists at universities, at government laboratories, and in industry. We must acknowledge the appropriate and valuable role that each of us has to play in working toward solving the problems of tomorrow. Because there is no doubt in my mind that as the world population grows to the ever nearer milestone of 10 billion people and as we realize more and more that agricultural practices must be sustainable in the long term and must, therefore, preserve and enhance the environment in which we all live, the relevance and need for plant pathologists will be even greater than it is today.

\section{LITERATURE CITED}

1. Jones, L. R. 1914. Problems and progress in plant pathology. Am. J. Bot. 1:97-111.

2. Lane, N. 1998. Quoted on Page 4D in: "Common vision could propel nation's new science team" by Tim Friend. USA Today, September 15, 1998.

3. Lyman, G. R. 1919. The unification of American botany. Science 39:339-345.

4. Sagan, C. 1995. The Demon Haunted World. Random House, New York.

5. Woteki, C. 1997. Sidebar quotation on Page 3 in: National Agricultural Research, Extension, Education, and Economics Advisory Board: 1997 Annual Report. V. L. Lechtenberg, chair. U.S. Dep. Agric., Washington, DC. 